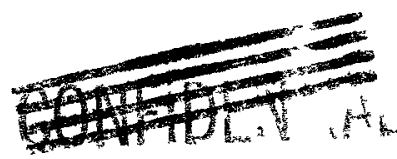

\title{
DENSITY AND VISCOSITY \\ OF SOLUTIONS IN THE TRIBUTYL PHOSPHATE PROCESS FOR URANIUM RECOVERY
}

BY

L. L. BURGER AND GM. SLANSKY TECHICA BIOSIONS

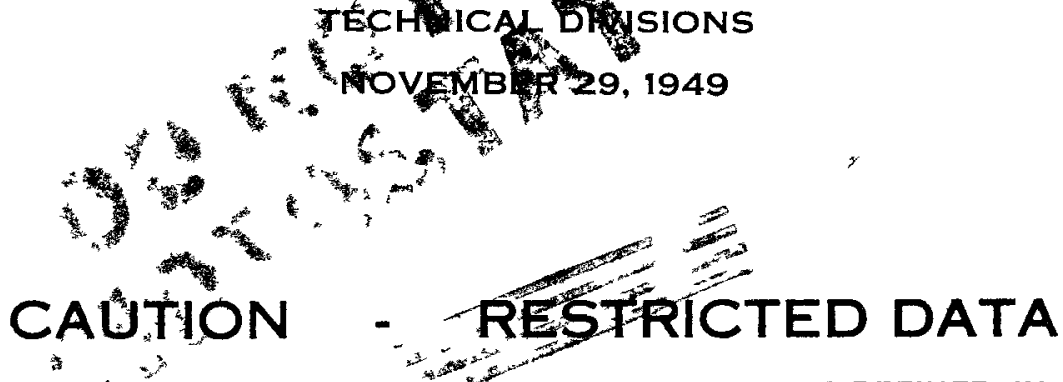

THIS DOCUMENT CONTAINS RESTRICTED DATA AS DEFINED IN THE ATOMIC ENERGY ACT OF 1946 WHICH AFFECTS THE NATIONAL DEFENSE OF THE UNITED STATES ITS TRANSMITTAL OR THE DISCLOSURE OF ITS CONTENTS IN ANY MANNER TO AN UNAUTHORIZED PERSON IS PROHIBITED AND MAY RESULT IN SEVERE PENALTIES UNDER APPLICABLE FEDERAL LAWS

\section{HANFORD WORKS} RICHLAND, WASHINGTON =

\section{GENERAL ELECTRIC}




\section{DISCLAIMER}

This report was prepared as an account of work sponsored by an agency of the United States Government. Neither the United States Government nor any agency Thereof, nor any of their employees, makes any warranty, express or implied, or assumes any legal liability or responsibility for the accuracy, completeness, or usefulness of any information, apparatus, product, or process disclosed, or represents that its use would not infringe privately owned rights. Reference herein to any specific commercial product, process, or service by trade name, trademark, manufacturer, or otherwise does not necessarily constitute or imply its endorsement, recommendation, or favoring by the United States Government or any agency thereof. The views and opinions of authors expressed herein do not necessarily state or reflect those of the United States Government or any agency thereof. 


\section{DISCLAIMER}

Portions of this document may be illegible in electronic image products. Images are produced from the best available original document. 


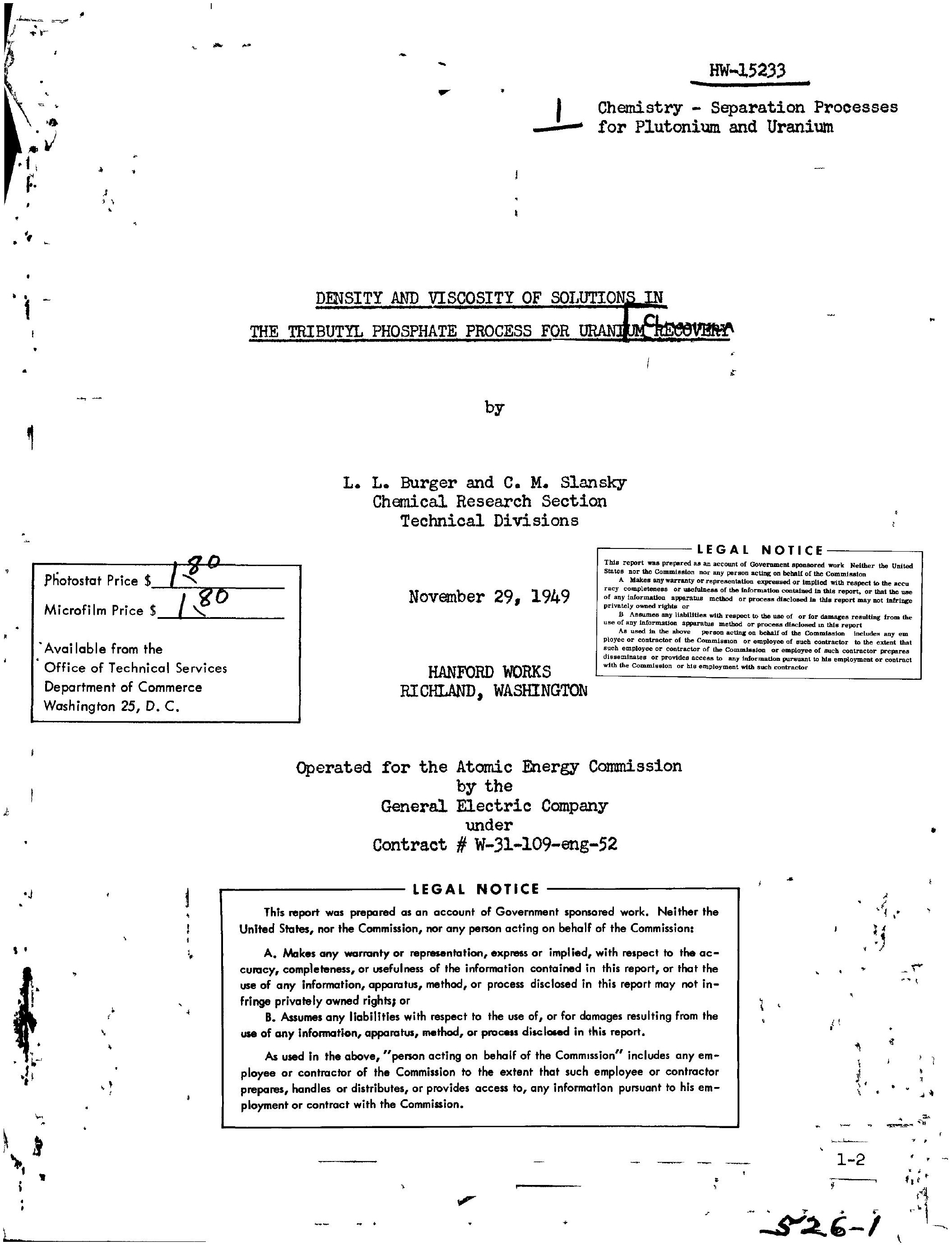




\section{3 \\ DENSITY AND VISCOSITY OF SOLUTIONS IN \\ THE TR IBUTYL PHOSPHATE PROCESS FOR URANIUM RECOVERY}

\section{INTRODUCTION}

The use of TBP (tributyl phosphate) for the recovery of uraptum from waste solution by solvent extraction has been studied at ORNI. (I) In that work hexane and "Varsol" have been employed as diluents for the TBP. Deo Base has been considered as a diluent due to its low cost, availability and relatively high flash point $\left(170^{\circ} \mathrm{F}.\right)$. It is a predominantly paraffinic hydrocarbon mixture boiling within the kerosene range and has a higher viscosity than hexane and "Varsol". The question then arises as to whether higher viscosities of the Deo Base - TBP systems, and a change in density differences between the two phases will lead to unsatisfactory column operation. The present discussion has as its primary purpose the presentation of preliminary density and viscosity date which may be of value in answering that question.

\section{SUMMARY AND CONCIUSION}

1. Density and viscosity data for solutions of $\mathrm{UO}_{2}\left(\mathrm{NO}_{3}\right)_{2}$ and $\mathrm{HNO}_{3}$ in TBP mixtures are presented.

2. The density of a $15 \%$ by volume TBP solution in Deo Base changes on saturation with $\mathrm{UO}_{2}\left(\mathrm{NO}_{3}\right)_{2}$ from 0.808 to 0.891 gms/cc at $25^{\circ} \mathrm{C}$. The viscosity changes from 18.3 millipolses to 25 millipoises. The effect of $\mathrm{HNO}_{3}$ on these properties, especially viscosity, is much smaller.

A typical aqueous phase may vary in density from about 1.24 to 1.14 gms/cc while the viscosity changes from 14.4 to 13.1 millipoises. The differences in densities between the two phases $1 \mathrm{~s}^{\mathrm{a}}$ nearly the same as for Redox IA operation.

3. While the viscosity of the organic phase is Iairly high, compared to the hexone solutions of the Redox Process, the changes in viscosity accompanying uranium extraction are relatively smell.

4. Density and $\forall i$ scosity data for $15 \%$ TBP in Deo Base suggest that this solution does not deviate ereatly from ideality but a small positive deviation from Raoult's law might be expected. The properties of solutions of $\mathrm{HNO}_{3}, \mathrm{UO}_{2}\left(\mathrm{NO}_{3}\right)_{2}$ and water in TBP are those expected as a result of strong interraction between the oxygen from the phosphate and molecules containing vacant orbitals or molecules capable of being polarized easily.

5. From the point of view of the variables, viscosity and density, it would appear that the solutions encountered in the TBP process.neither introduce sufficiently detrimentel factors nor possess oroperties far enough removed from successful operating experience such that they cannot be compensated for in colum design.

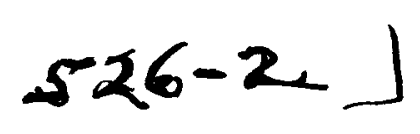


III. RESULTS

TBP is a colorless o1ly liquid having a bolling point of $289^{\circ} \mathrm{C}$. at $760 \mathrm{~mm}$. The density at $25^{\circ} \mathrm{C}$. is 0.9730 and the viscosity 33.2 millipolses. It is nearly insoluble in water, about $0.2 \mathrm{gm}$ per liter. The solubility of water in TBP is, on the other hand, about 54 gms per liter or 50 mole per cent. The vapor pressurc and some chemical properties are discussed in HW-15172.

Deo Base is a petroleum fraction of the kerosene range having a bolling point of about 220 to $270^{\circ} \mathrm{C}$. The donsity at $25^{\circ} \mathrm{C}$. is 0.7804 and the viscosity 17.3 millipoises.

A solution of 15 volumo per cent in Deo Base is not far from an ideal solution. The calculated donsity is 0.809 compared to an observed value, of 0.808 at $25^{\circ} \mathrm{C}$. The viscosity, a better indication of ideality, is calculated to be 18.8 millipoises compared to an observed value or 18.3. The difference of two per cent would indicate a slight positive deviation from Raoult's law.

In Table I the density, viscosity and composition of a number of solutions are listed. Figure 1 shows the density as a function of $\mathrm{UO}_{2}\left(\mathrm{NO}_{3}\right)_{2}$ concentration while Figure 2 is a similar plot of the viscosity. The density data can be related to composition by the equation

$$
\rho_{25^{\circ} \mathrm{C} .}=0.808+0.328 \mathrm{M}_{2}\left(\mathrm{NO}_{3}\right)_{2}+0.028 \mathrm{M}_{\mathrm{HNO}_{3}}
$$

The curve in Figure $I$ is actually drawn through three points which have a nitric acid concentration of $0.03 \mathrm{M}$.

Table I

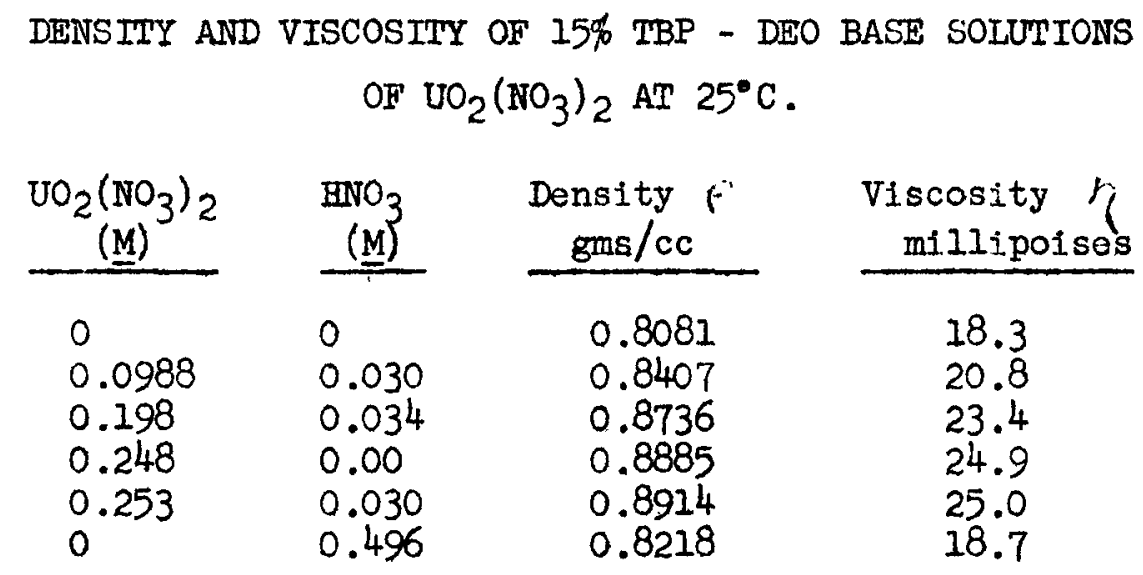

The change in density and viscosity going from zero uranium content to saturation, $0.25 \mathrm{M}$., is relatively small by comparison to the hexone solutions encountered in the Redox Process. This results from the small range in concentration together with the comparatively high viscosity of the inert solvent Deo Base.

The effect of nitric acid on the density and especially on the viscosity is much smaller than of uranyl nitrate. Saturating the TBP - Deo Base with nitric acid, 
giving a solution $0.5 \mathrm{M}$ in $\mathrm{HNO}_{3}$ or a mole rat1o of $\mathrm{HNO}_{3}$ to $\mathrm{TBP}$ of $1: 1$, only rejsed the viscosity from 18.3 to 18.7 millipolses. It may be mentioned that water added to dry TBP or dry TBP - Deo Base mixtures has an affect on the viscosity slightly greater in magnitude than has $\mathrm{HNO}_{3}$. This is undoubtedly the rosult of strong hydrogen bonds which may lead to a chain structure in TBP - water mixtures.

A point of interest here is that the water content of TBP solutions decreases rapidly as uranyl nitrate is dissolved. Not only are hydrogen bonds holding water to TBP broken but the water molecules from the coordination sphere of $\mathrm{UO}_{2}\left(\mathrm{NO}_{3}\right)_{2}$ are eliminated when the uranyl group is surrounded by two TBP molecules. The steric hindrance imposed by the large $-0-\mathrm{C}_{4} \mathrm{H} 9$ groups may be a factor in water elimination. The high complexing ability or TBP for $\mathrm{UO}_{2}\left(\mathrm{NO}_{3}\right)_{2}$ compared to that of the aliphatic ketones and ethers suggests that the oxygen atom involved is very basic in charactor.

Data for representative aquaous solutions for a typical countercurrent extraction are listed in Table II. Solution IAS is the scrub solution, IAF, the metal feed, WR 4 represents a composition in the vicinity of the feed plate and WR-8 and WR-10 correspond to compositions towards the bottom of the extraction saction.

Table II

DENSTTY AND VISCOSITY AT $25^{\circ} \mathrm{C}$. OF AQUEOUS SOLUTIONS FOR URANIUM RECOVERY

\begin{tabular}{|c|c|c|c|c|c|c|c|}
\hline Solution & $\begin{array}{c}\mathrm{UO}_{2}\left(\mathrm{NO}_{3}\right)_{2} \\
(\underline{\mathrm{M}})^{2}\end{array}$ & $\begin{array}{c}\mathrm{Na}_{2} \mathrm{SO}_{4} \\
(\underline{\mathrm{M}})\end{array}$ & $\begin{array}{c}\mathrm{Na}_{3} \mathrm{PO}_{4} \\
(\mathrm{M})\end{array}$ & $\begin{array}{c}\mathrm{NaNO}_{3} \\
(\mathrm{M})\end{array}$ & $\begin{array}{l}\mathrm{HNO}_{3} \\
(\underline{M})\end{array}$ & $\begin{array}{l}\text { Density } \\
(\mathrm{gms} / \mathrm{cc})\end{array}$ & $\begin{array}{l}\text { Viscosity } \\
\text { (millipolses) }\end{array}$ \\
\hline IAS & 0 & 0 & 0 & 0 & 4.0 & 1.1591 & \\
\hline IAF & 0.188 & 0.18 & 0.16 & 1.81 & 3.0 & 1.2826 & 16.4 \\
\hline WR-4 & 0.152 & 0.12 & 0.10 & 1.21 & 3.2 & 1.2407 & 14.3 \\
\hline$W R-B$ & 0.136 & 0.12 & 0.10 & 1.21 & 3.2 & 1.2370 & \\
\hline$W R-10$ & 0.015 & 0.12 & 0.10 & 1.21 & 3.1 & 1.1976 & 13.2 \\
\hline
\end{tabular}

Two factors of importance in column operation are the density difference between phases and the viscosity of the continuous phase. Comparison of data from Tables I and II show that the density difference changes from 0.27 in the scrub section through 0.35 at the feed plate to about 0.39 at the bottom of the column. This compares to 0.36 for the density difference in a IA Redox extraction. The lower aqueous viscosity as compared to a Redox IA system indicates a considerably higher sedimentation velocity for the organic phase droplets in the TBP system as compared to Redox. Also the organic phase is more viscous than in Redox, i.e., a range of 18.3 to 25.0 rallitipoises for 15\% TBP - Deo Baso compared to 6 to 13 millipoises for hexone in the Redox system. This would suggest a somewhat lower diffusion rate in the organic phase. On the other hand dirfusion in the aqueous phase by the same argument would be more rapid. It is, of course, possible to modify both the density difference and the viscosity of the organic phase by substituting a small amount of another inert liquid for Doo Base, or changing the ratio of TBP to Deo Base.

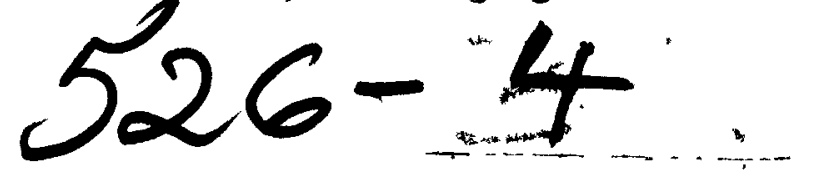


1

The above data were obtained from a few exploratory experiments and do not, of course, give the complete picture. From the information at hand, though, it is probable that these solutions neither introduce sufficiently detrimental factors nor posses properties far enough removed from successful operating experience such that they cannot be compensated for in column design.

\section{REFERENCES}

1. ORNL-258, 260.

2. Glasston, Laidler and Eyring. Theory of Rate Processes. 


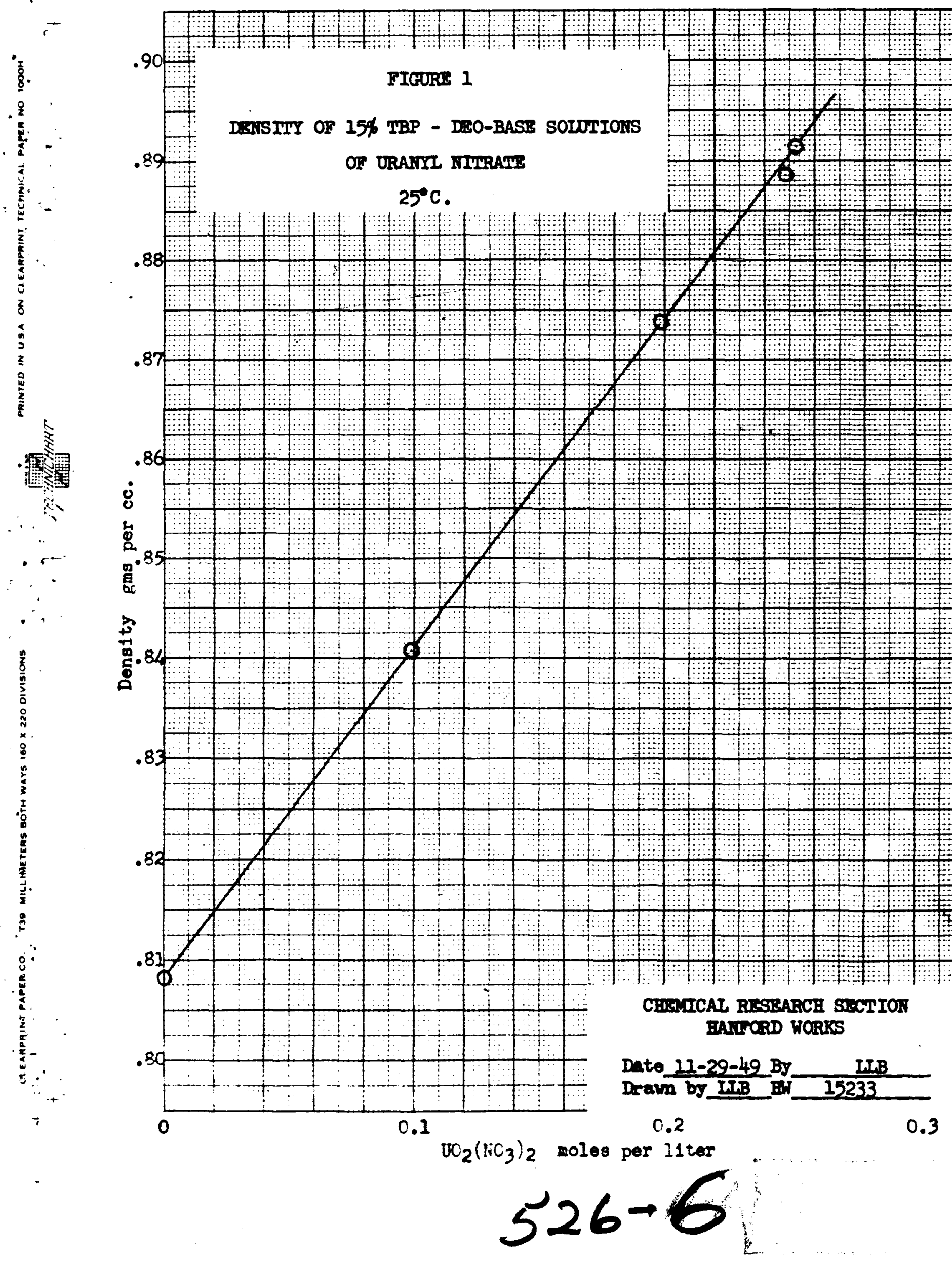




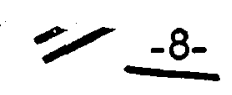

패-15233

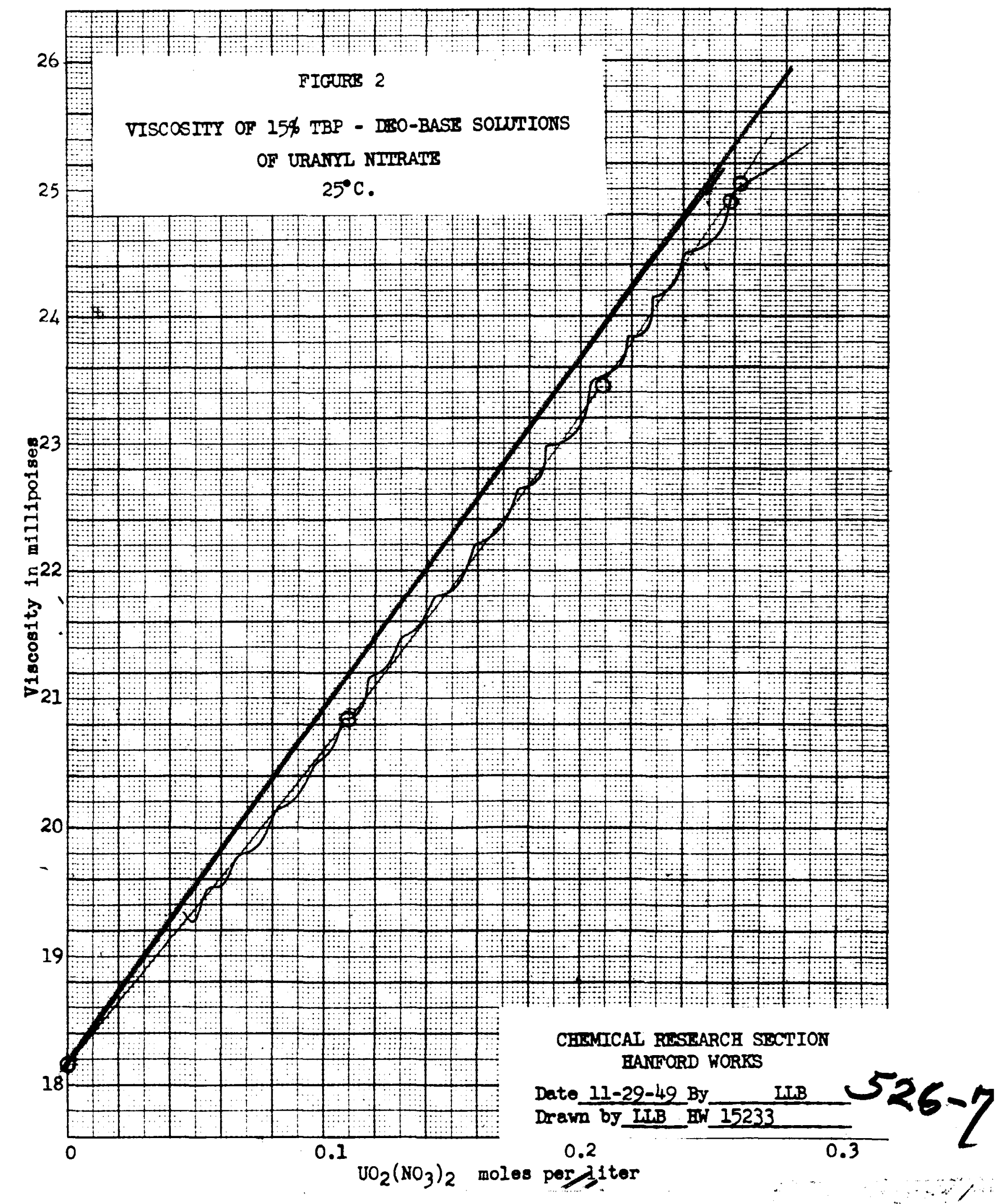

